\section{Breaking Boundaries: Female Biblical In- terpreters Who Challenged the Status Quo, edited by Nancy Calvert-Koyzis and Heather Weir}

New York and London: T\&T Clark, 20I0 | viii + 2I4 pages | ISBN: 978-0-56759-503-4 (hardback) £70.00 | ISBN: 978-0-56737-503-2 (paperback) £24.99

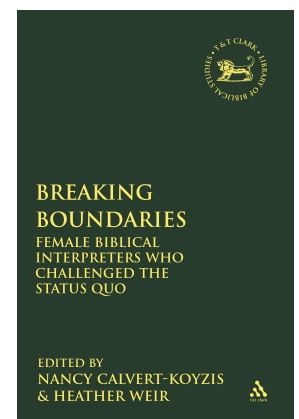

Nancy Calvert-Koyzis and Heather Weir are familiar to scholars interested in the recovery of women's interpretations of the Bible as the editors of the 2009 volume Strangely Familar: Protofeminist Interpretation of Patriarchal Biblical Texts (Atlanta: SBL, 2009). Weir also collaborated with Marion Ann Taylor on an earlier volume concerning nineteenth-century women's interpretations of Genesis (Let Her Speak for Herself: Nineteenth-Century Women Writing on Women in Genesis [Waco: Baylor University Press, 2006]). The business of recovering women interpreters of biblical texts is still in its early stages of research, and the field owes a deep debt of gratitude to these intrepid investigators and their collaborators who have contributed to Breaking Boundaries. Although one or two of the contributors in Breaking Boundaries are working from their primary field of training, the majority are stretching themselves to perform scholarly research that goes far beyond the areas in which they were trained. These persons are, in both senses of the term, amateurs. They work out of love for their subject and bring to light much that is valuable. But one cannot read this volume without an acute sense of the lack of professional depth that characterizes most of the articles. Yet if we waited for the professional historians of these various time periods to deal with the issues raised here, we might well wait forever. Thus gratitude tempers critique.

The design of the volume is elusive. The title, Breaking Boundaries, suggests that the figures considered will have been transgressive in various ways, and while this is characteristic of many, some of the figures considered seem 
to have used their writings to reinforce dominant ideologies and to have stayed well within the boundaries of what was considered proper for educated women of their time. That is not to say that these women are not of interest to the recovery of the history of women biblical interpreters, only that the title may protest a bit too much about the nature of their activities. Similarly, the chronological scope is odd. There is one woman from late antiquity, one from the Elizabethan/Jacobean period, and the rest from nineteenth- and early twentieth-century Great Britain and North America. Limiting the book to the latter cultural location would have given it a clearer focus. Also odd is the fact that two articles on Harriet Beecher Stowe by the same author are neither grouped together nor coordinated with one another.

One aspect of editorial design is particularly welcome. The editors appear to have asked writers to be particularly careful to establish the intellectual and socio-cultural context of each of the women considered, and in the best of the articles this contextualization lends a fascinating light on the hermeneutical issues involved in the particular interpreter's work.

Brian Sowers, who is trained in classics and early Christian literature, examines the Homeric cento of Eudocia, the wife of emperor Theodosius II (fifth century). In some respects the account of Eudocia's literary remains reads like a narrative by Jorge Luis Borges, since the manuscript evidence is insanely tricky, and many of the accounts about Eudocia are tinged with legend. The literary form of the cento itself involved the composition of a poem (here the life of Christ) using only lines already extant in Homer or another classical author. Eudocia's own cento was not an original composition but a revision of that of Patricius. Her revision of Patricius was then revised by Optimus, etc. The object of inquiry threatens to vanish into uncertainty. Sowers is able to show, however, with some persuasiveness, that one can still see the hand of Eudocia at work. Particularly through her cento's presentation of Jesus's encounter with the Samaritan woman, she focuses issues of concern in her own time with respect to women's options of celibacy or marriage.

Caryn A. Reeder gives a good introduction to the intellectual context and major work of Aemilia Lanyer (Salve Deus Rex Judaeorum, I6I I), the remarkable feminist poet of early seventeenth century England. Her work is appropriately situated within the querelle des femmes, the centuries-long European literary dispute over the virtues and vices of women. Lanyer's radical hermeneutics in reinterpreting Gen I-3 (through the voice of Pilate's wife, no less) in contradiction to the prevailing misogynistic interpretation is remarkable. Lanyer's work is readily available on the web at several sites and 
deserves to be integrated into the history of the reception of Gen I-3 much more centrally.

Heather E. Weir discusses Sarah Trimmer's An Easy Introduction to the Knowledge of Nature and Reading the Holy Scriptures (1780). Trimmer was an author of books in religious education for children. Weir persuasively situates her less in the context of early science or environmental education, as others have considered her, and more in the context of natural theology. Nevertheless, it is difficult to see exactly how Trimmer qualifies as one who broke boundaries, as she seems to communicate in a genre acceptable for women writers, more or less what other educated and progressive men were doing at the time.

It is even more difficult to bestow the epithet of boundary breaker on Eliza Smith's The Battles of the Bible (1852), which is the topic of Bernon Lee's essay. Smith cast her book as a conversation between a grandfather and his grandchildren concerning the battles narrated in the Bible. What Lee helpfully brings out is how Smith's interpretation often picks up on isolated details in order to advance a social agenda of middle class virtues (industry, honesty, self control, etc.) in the context of the Scottish middle class's attempt to "pry the church apart from upper-class interests" (8I) in order to address the plight of the working class. While a fascinating account of socio-cultural struggles played out in biblical education, it is difficult to see how Smith's gender is interpretively significant to the nature of what she did. Her class and social location seem much more germane.

One sympathizes with the task of J. Glen Taylor, who attempts to contextualize Joana J. Greswell's Grammatical Analysis of the Hebrew Psalter (I 873). Though some things are known about Greswell's family, very little is known about her personally. Moreover, her work, as a technical work of scholarship, lends itself only with difficulty to ideological placement. Taylor does draw attention to the fact that Greswell's book was prefaced by endorsements by male scholars. Since this was a feature of other women's books in the nineteenth century, it would have been useful to explore this phenomenon comparatively, so as to frame more clearly the means by which women negotiated the resistance to their entry into largely male fields of scholarship.

Nancy Calvert-Koyzis contributes two essays on Harriet Beecher Stowe's interpretations of the Virgin Mary and Mary Magdalene in mid-nineteenthcentury America. The Virgin Mary is interpreted in relation to the Victorian cult of true womanhood and the theory of separate spheres of women and men. But Stowe's interpretations are also related in this article to her 
own personal history of the death of two of her children. The ambivalence of Beecher Stowe's own public role and her championing of a more private role for women is palpable. Nevertheless, her radical call to reform the nation in the image of feminine virtues is well articulated. The essay on Mary Magdalene underscores the conflict among women interpreters of the era concerning whether to accept or contest the traditional association of Mary Magdalene with the "sinful woman" of Luke 7. These essays would have been more effective if they had been conceptualized more as a coordinated pair of articles and juxtaposed in the volume.

Beth Bidlack's essay on Olympia Brown (I $825-1926$ ) provides a good biographical and contextual account of this pioneer in women's ordination and women's suffrage, but one wishes that it was more thesis-driven. Similarly, Rebecca G.S. Idestrom's essay on Elizabeth Mary MacDonald (I897-I984), provides an engaging report on the dissertation of the first woman to get a Ph.D. in the department of Near and Middle Eastern Studies from the University of Toronto, who wrote on "The Position of Women as Reflected in Semitic Codes of Law" (1928), but the essay never quite finds a focus.

Perhaps the best essay in the book is that of Kristin Kobes Du Mez on the work of Katharine Bushnell (I 855 -1946) and Lee Anna Starr (I $853-1937$ ), two women who engaged in what we would recognize as feminist hermeneutics but who rejected both the iconoclastic freedom embraced by Elizabeth Cady Stanton's approach to the Bible and the historicizing hermeneutics of the emerging higher criticism. As Du Mez argues, their quite sophisticated and bold hermeneutics was largely disregarded because "Bushnell and Starr did not fit securely within either the conservative or the liberal factions of an increasingly polarized faith" (I66). One hopes that Du Mez's article will help restore these women to a more significant place within the history of feminist scholarship.

Though Breaking Boundaries has its shortcomings, the intellectual work of the recovery of women interpreters remains in its infancy, and one can be grateful for what has been retrieved and presented here. The volume does, however, point toward the need of biblical scholars to collaborate more fully with our counterparts in the intellectual and cultural history of the periods in which we are interested. The result of such collaborations will certainly enrich both biblical studies and historical studies. 